\title{
229 適応格子法を用いた円柱まわりの缺撃波解析
}

\author{
小沢 拓(慶大[院] $)^{\star_{1}} \bigcirc$ 棚橋 隆彦(慶大理工) ${ }^{\star_{2}}$ 鈴木 裕二郎(NTT) ${ }^{\star 3}$.

\section{Shock Wave Diffraction around Circular Cylinder \\ Using Unstructured Adaptive Meshes} \\ Taku OZAWA $^{\bigcirc}$, Takahiko TANAHASHI , Yujiro SUZUKI
}

\begin{abstract}
The study of flow around a circular cylinder is one of the most important problems in not only basic research but also analysis of a complexity object. Under supersonic flow in particular, the numerical result is insufficient for the lack of resolution in the complicated flow around passing through circular cylinder. Therefore, we used unstructured adaptive meshes which can automatically divide elements only in the region of large variation. As the result, the reflection phenomena was analyzed from the numerical results. The effects of parameter of the indicator were examined.
\end{abstract}

\section{1. 緒 言}

数 值流 体力 学 (CFD:Computational Fluid Dynamics)においては, スーパーコンピュータの発達 とともに解析能力が飛躍的に向上してきている。しか し, 物体形状が複雑になるにつれて計算格子をどのよ うにしたらうまく分布させられるかという問題が生 じてきた。

格子付加型の適応格子法が開発された目的は，衝撃 波などの流れの変化の激しいところでは，自動的に格 子を細かくし，逆に，変化の緩やかなところでは格子 を粗くする(初期格子の大きさまで)ことで解析に必要 な計算費用を最小限にすることである。よって格子を 分割，削除すへきセルにマークをつけるマーキングが 重要となる。マーキングの判断に用いられるのが指針 值であり，その計算に用いる物理量が評価值である。

そこで本研究では，円柱まわりの衝撃波解析を行い， 密度, 渦度, それらの混合值の各評価值を用いた解析 結果の相違について検討し，今後の規範となる指針值 と評価值の適用例を提示した。

\section{2. 数值解析法}

\section{1 基磁方程式}

支配方程式は，連続の式，二次元 Euler 方程式，工 ネルギーの保存式である。それらの方程式は，代表速 度及び代表長さにより無次元化することで以下のよ うになる。

$$
\frac{\partial \boldsymbol{Q}}{\partial t}+\frac{\partial \boldsymbol{F}}{\partial x}+\frac{\partial \boldsymbol{G}}{\partial y}=0
$$

${ }^{\star} 1$ 慶応義熟大学大学院(广223 横泜市港北区日吉 3-14-1) *2 正員, 慶応義塾大学理工学部

*3 NTT 侏) (₹163-19 新宿区西新宿 3-19-2)
ここで, 各ベクトル $Q, F, G$ は以下のように与えられ

る。

$Q=\left(\begin{array}{l}\rho \\ \rho u \\ \rho v \\ e\end{array}\right) \quad F=\left(\begin{array}{l}\rho u \\ \rho u^{2}+p \\ \rho u v \\ u(e+p)\end{array}\right) \quad \dot{G}=\left(\begin{array}{l}\rho v \\ \rho u v \\ \rho v^{2}+p \\ v(e+p)\end{array}\right)$

ここで， $\rho$ は密度， $\boldsymbol{u}, \boldsymbol{v}$ はそれぞれの速度の $\mathrm{x}$, $\mathrm{y}$ 成分, $p$ は圧力, $e$ は単位体積あたりの全エネルギ 一である。

\section{2 空間スキーム}

セル境界 $k$ での非粘性数值流束は MUSCL 法によ り高次精度化した。また，制限関数には minmod limiter を適用した。これにより, 以下の式を得ること が出来る。

$\widetilde{\boldsymbol{F}}_{k}=\frac{1}{2}\left\{\widetilde{\boldsymbol{F}}\left(\boldsymbol{Q}_{i}^{k}\right)+\widetilde{\boldsymbol{F}}\left(Q_{j}^{k}\right)-\left|\boldsymbol{A}_{k}\right|\left(Q_{j}^{k}-Q_{i}^{k}\right)\right\}$

ここで, $\boldsymbol{A}_{k}$ はヤコビアン行列である。

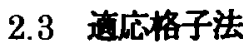

格子付加型の適応の場合, 適応後に格子の “構造” を再び決めてやる必要がある。これを格子の再構成と いう。再構成は，大きく分けてマーキング，格子削除， 格子分割の三つの手順にしたがって行われる。

それらの中でも特に重要となるのがマーキングで あるが，これは，格子を分割あるいは削除すべきセル にマークを付ける作業である。

評価値を密度にしたときは，付加，削除の判断には Löhner の指針值(1)を用いた。 


$$
\begin{aligned}
& E_{i}=\max \left(E_{i \xi}, E_{i \eta}\right) \\
& E_{i \xi}=\frac{\left|U_{E}-2 U_{i}+U_{W}\right|}{\left|U_{E}-\rho_{i}\right|+\left|U_{i}-U_{W}\right|+c_{\xi}} \\
& c_{\xi}=\delta\left(\left|U_{E}\right|+2\left|U_{i}\right|+\left|U_{W}\right|\right. \\
& E_{i \eta}=\frac{\left|U_{N}-2 U_{i}+U_{S}\right|}{\left|U_{N}-U_{i}\right|+\left|U_{i}-U_{S}\right|+c_{\eta}} \\
& c_{\eta}=\delta\left(\left|U_{N}\right|+2\left|U_{i}\right|+\left|U_{S}\right|\right. \\
& \text { ただし, } \delta=0.05 \text { である。また, この場合は } U=\rho \\
& \text { である。 } \\
& \text { 次に, 評価値を渦度にしたときは, Dannenhoffer } \\
& \text { の指針値(2)を用いた。 }
\end{aligned}
$$$$
\text { である。 }
$$

$$
\begin{aligned}
& E_{i}=\frac{c u r l V-c u r l V_{\min }}{c u r l V_{\max }-c u r l V_{\min }} \\
& c u r l V=\frac{\partial u}{\partial y}-\frac{\partial v}{\partial x}
\end{aligned}
$$

$E_{i}>T_{d i v}$ ならば分割マークを, $E_{i}<T_{r m}$ ならば削 除マークをセルに付ける。分割之削除は分割を優先す る。

\section{3. 円柱まわりの得波の反射と回折}

\section{1 泟波の反射之回折}

入射衝撃波(Incident Shock)が進行し円柱とぶつか ると，衝擊波は円柱表面で反射する(Fig.1(a))。この正 常反射衝揧波之入射衝揧波の合点は, 初めのうちは円 柱表面に沿って伝播するが，正常反射がマッ八反射に 変わると，この合点は円柱表面上を蜼れ，マッハステ

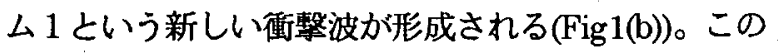
$3 つ の$ 衝搫波で形成される合点のことを三重点 1 と 呼ぶ。さらに入射衝撃波が進行すると, 円柱後部で回 折したマッハステムが後部淀み点で反射し，その反射 したマッハステムは境界層と干渉する。その後マッハ ステムは上流へ伝播し前方の王縮波に出会うと急速 に強まり、これとも干渉して著しい剥離とラムタ型衝 揧波を発生させる。剥離点は, 衝撃波の伝播と共に上 流へ移動し，剥離点後方では，円柱表面から蜼れた非 粘性域まで近流が及んでいる。逆流域では，流れの方 向に圧力の急上昇部があり，そのため複雑な流れとな $3^{(3),(4)}$ (Fig.2)。

\section{2 数做解析結果}

計算領域は半円柱の中心が原点で直径を 1 として,
半円柱の中心から外側境界までの距離が 3 の半円形 である(初期格子数 510)。最小格子幅は 4 回の適応後 で $3.0 \times 10^{-3}$ である。入射衝慗波を-0.7 の位置に立て, あらかじめ適応し人射衝撃波近傍の格子を細かくし た後，計算を開始した。適応のパラメータはできるだ け格子数を減少させるように決定した。また現象が $\mathrm{x}$ 軸対称であるので，できるだけ格子の增加を防ぐため に対称条件を導入した。計算条件をTab.1 に示す。ま た，本研究では評価値(指針値の計算に用いる物理量) に密度, 渦度, それらの混合值の 3 つを用いたが，そ れぞれに対する敷居值をTab.2 に示す。

Tab.1 Calculating condition 1

\begin{tabular}{|c|c|}
\hline$M S$ & 2.81 \\
\hline$C F L$ & 0.2 \\
\hline adapt.frequency & every 5 time steps \\
\hline max cell level & 4 \\
\hline
\end{tabular}

Tab. 2 Calculating condition 2

\begin{tabular}{|c|c|c|}
\hline parameter & $T_{\text {div }}$ & $T_{m}$ \\
\hline density & $1.0 \times 10^{-1}$ & $5.0 \times 10^{-2}$ \\
\hline vorticity & $5.0 \times 10^{-4}$ & $2.5 \times 10^{-4}$ \\
\hline density\&vorticity & $1.0 \times 10^{-3}$ & $5.0 \times 10^{-4}$ \\
\hline
\end{tabular}

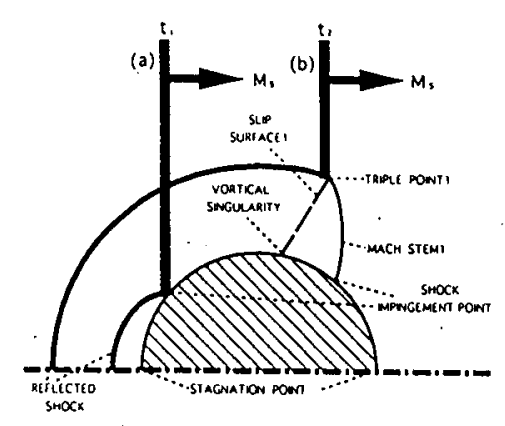

Fig.1 Shock wave diffraction around circular cylinder

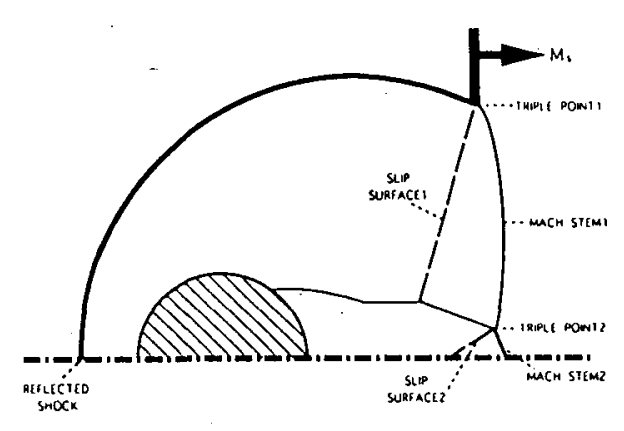

Fig.2 Shock wave reflection around circular cylinder 

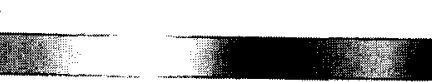

$1.5 \times 10^{-1}$

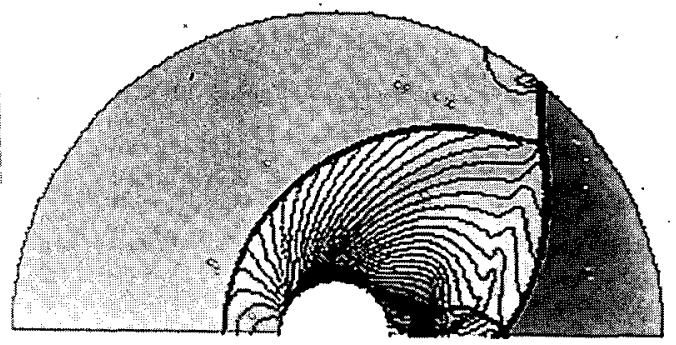

(a)Indicator's parameter : density

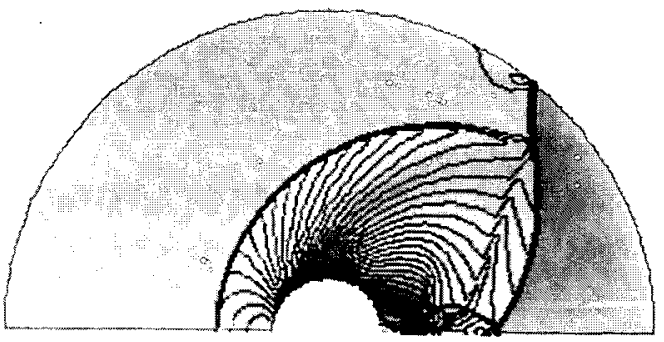

(b) Indicator's parameter : vorticity

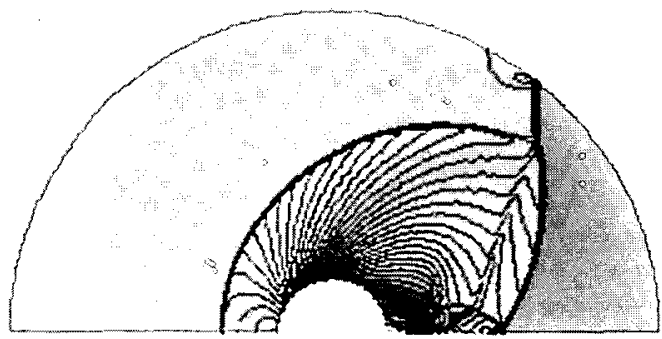

(c)Indicator's parameter : density\&vorticity

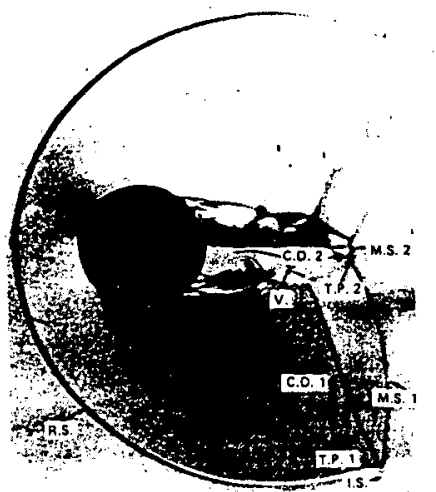

(d) Experiment ${ }^{(3)}$

Fig.3 Density contour $\left(M_{S}=2.81, \mathrm{t}=0.91\right)$

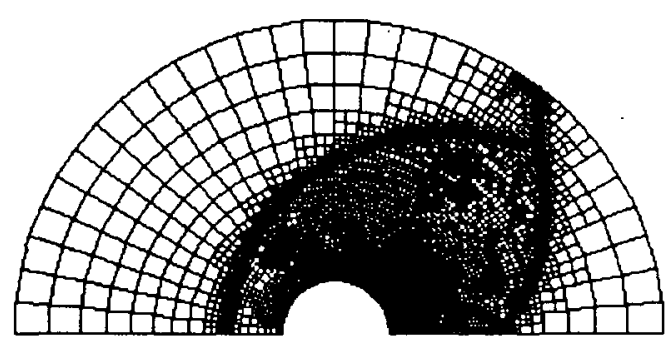

(a)Indicator's parameter : density (32448 mesh)

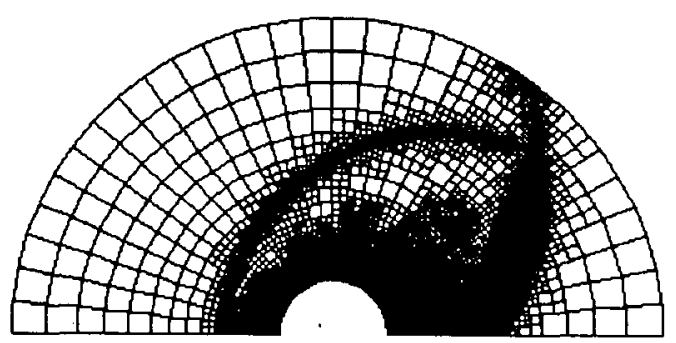

(b)Indicator's parameter : vorticity (56616 mesh)

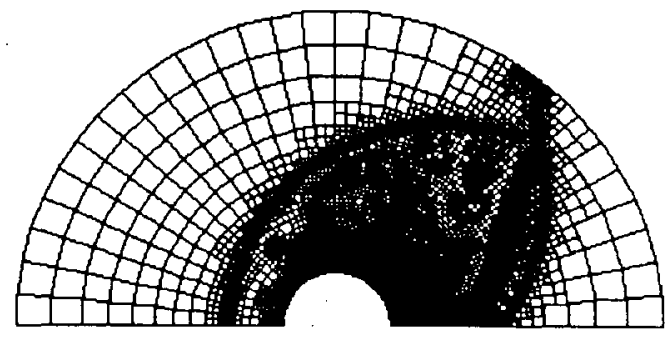

(c)Indicator's parameter : density\&vorticity (45720 mesh)

Fig. 4 computational grid

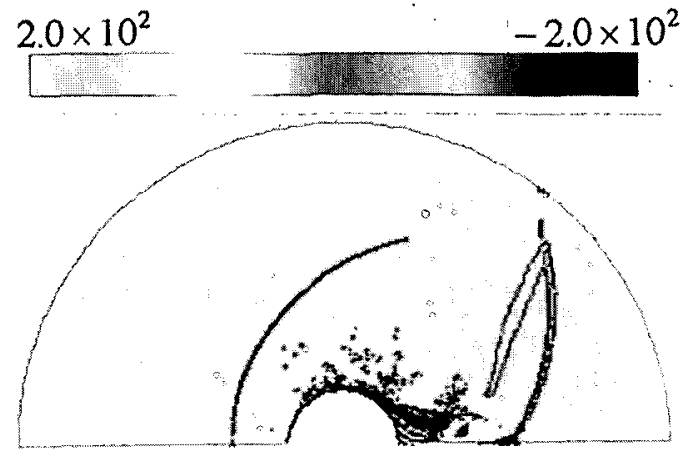

Fig. 5 vorticity contour 


\section{3 湌得}

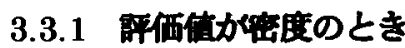

結果(Fig.3(a))を見てみると，衝撃波が細くとらえら れているのが分かる。次にメッシュ図(Fig.4(a))を見て みると，衝撃波の部分に格子が集まっている。さらに 円柱後部の複雑な流れの部分にも格子が集まってお り、これにより現象を詳細にとらえられるようになっ ている。

滑り線の前後において密度は不連続である。これに より滑り線の部分で格子が分割され，骬り線の存在は 確認できるものの, 実験結果(Fig3(d)) と比較すると滑 り線のとらえかたが甘いことがわかる。またメッシュ 図を見ても，格子が削除しきれていない箇所も目につ く。

以上のことより，評価値を密度のみにして計算させ た結果は全体的には良好であるが，細かいところで現 象をとらえきれていないことが分かる。

\subsection{2 評価值が瀜度のとき}

まずLöhner の指針値を用いて計算させてみたとこ ろ，格子の分割が多くなりすぎて，格子数が 10 万を 超えてしまった。これは Löhner の式(5)の特性による ものである。よって Dannenhoffer の指針値を用いる ことにした。

等渦度線図(Fig5)を参考にして，敷居値をいくつか 変えて計算させてみた。 その結果, Tab.2 に表示した 值にしたときか，格子数は多くなるものの良好な結果 を示した(Fig3(b))。滑り線の解析においては，他の評 価值を用いた解析に比ぺて解像度が優れていること も結果より分かる。メッシュ図(Fig4(b))を見ても，滑 り線の部分に格子が多くなっているのが分かる。

\subsection{3 䀒価值力㑻度と瀜度の混合值のとき}

評価値を消度にして行った解析結果は，良好なもの ではあったものの，格子数が多くなってしまったこと が問題点であった。そこで評価值に密度と渦度の混合 の値を用いて計算させてみた。この際, 密度に関して は Löhner の指針値，渦度に関しては Dannenhoffer の指針值を適用した。また，分割の時にはより大きい 值を，削除の時にはより小さな值を用いるようにした。 これにより両者の性質が際立ち, 分割之削除がはっき り行われると考えられる。

結果を見ると, 衝撃波, 滑り線, 三重点の全てが良 くとらえられていることが分かる(Fig.3(c)）。実験結果 (Fig.3(d)) と比較しても非常に良好であると言える。さ らにメッシュ図(Fig.4(c))をみると，衝揧波と滑り線の 位置に格子が集まっていることが分かる。特に，衝撃 波之滑り線の間に削除されたスペースがあり，これに より格子数の減少か図られている。すなわち，各々の
性質がはっきりと現れており，指針値を湿合させたこ との利点が十分に現れている。

\section{4. 結 言}

（1）評価値を密度単独にすると，全体的に良好な結果 を得ることはできたが滑り線の解析には十分な 結果を得ることができなかった。

（2）評価値を渦度単独にすると，渦である滑り線の解 析は良好なものとなるが, Dannenhoffer の指針 値の感度の悪さのために三重点がとらえにくく， それを補うために分割の敷居值を小さくすると 格子数が多くなってしまった。

（3） 円柱まわりの橿擊波解析においては，評価值は密 度と渦度の混合值が適しており，それにより解析 において重要となる衝撃波; 滑り線, 三重点をよ り鮮明に, 少ない格子数でとらえられることが出 来た。

（4）Löhner の指針值は，感度がよく，格子数も少な くなるものの, 評価值の物理量が 0 付近での解析 には適していない。これに対して Dannenhoffer の指針値は分割と削除がはっきりし, 評価值の物 理量が0付近での解析にも適しているが, 敷居值 を定めるのか難しく，また格子数も多くなる。

\section{参考文献}

(1) Löhner,R., An Adaptive Finite Element Scheme for Transient Problems in CFD, Comput. Meths. Appl. Mech. Engrg., 61, (1987),323--338.

(2) Dannenhoffer,J.F. and Baron,J.R., Grid Adaptation for the 2--D Euler Equations, $A L A A$ Paper 85--0484, (1985).

(3) Bryson,A.E. and Gross,R.W.F., Diffraction of strong shocks by cones, cylinders, and spheres, Journal of Fluid Mechanics, Vol.10, (1961), 1. 16.

(4) Yang,J.Y., Liu Yen, and Lomax Harvard, Computation of Shock Wave Reflection by Circular Cylinders, AIAA J., Vol.25, No.5, (1987), 683-689. 